\title{
Assessment Accommodations for Foreign Pupils in the Light of Educational Justice: Empirical Research among Slovenian Primary School Teachers
}

MojCA Žveglič MiHelič

$\approx \quad$ The starting points of primary school pupils in a foreign country differ significantly from those of native pupils. In Slovenia, the knowledge of pupils who are foreign citizens (foreign pupils) may be assessed with different accommodations for no more than two years. The presented research conducted on a representative sample of 697 Slovenian primary school teachers addresses their perspectives, using a questionnaire, on assessment accommodations for foreign pupils. The following research questions are answered: 1) What are teachers' perceptions of assessment accommodations for foreign pupils; are there differences between teachers who had recently taught foreign pupils and those who had not? 2) Do generalist teachers have different perceptions than subject teachers do? 3) What kind of assessment accommodations do teachers practice for these pupils after the expiration of the two-year period; do generalist and subject teachers act differently? 4) Do teachers perceive assessment accommodations as being just? We demonstrate that teachers who have recent experience of teaching foreign pupils are more aware of the need for assessment accommodations than those who do not. The majority of the teachers accommodate assessment and grading even after the two-year period, especially generalist teachers. Additionally, some of them have lower expectations with regard to achieving knowledge standards for these pupils. While the majority of the teachers perceive accommodated assessment as being just, they are unsure of whether the period of allowed adjustments should be longer. This raises the questions about teachers' understanding of educational justice and the application of the principle of justice in practice.

Keywords: assessment accommodations; educational assessment and grading; justice in education; primary school teachers; pupils without Slovenian citizenship

1 University of Ljubljana, Faculty of Education, Slovenia; mojca.zveglic@pef.uni-lj.si. 


\section{Prilagajanje preverjanja in ocenjevanja znanja učencev tujcev $\mathrm{z}$ vidika šolske pravičnosti: izsledki raziskave med slovenskimi osnovnošolskimi učitelji}

MoJCA Žveglič MiHeLiČ

Izhodišča osnovnošolcev, ki so tuji državljani, se pomembno razlikujejo od izhodišč učencev, ki so slovenski državljani. Preverjanje in ocenjevanje znanja učencev, ki so tuji državljani (učenci tujci), se v Sloveniji lahko izvaja z različnimi prilagoditvami, a največ dve leti od vpisa učenca v slovensko osnovno šolo. V tem prispevku predstavljamo izsledke empirične raziskave, v kateri smo anketirali reprezentativni vzorec 697 slovenskih osnovnošolskih učiteljev glede njihovega pogleda na prilagoditve preverjanja in ocenjevanja znanja učencev tujcev. Odgovarjamo na naslednja raziskovalna vprašanja: 1) kakšna so stališča učiteljev o prilagoditvah preverjanja in ocenjevanja znanja učencev tujcev in ali se glede tega pojavljajo razlike med učitelji, ki poučujejo učence tujce, ter tistimi, ki poučujejo le slovenske državljane; 2) ali se stališča učiteljev razrednega pouka o prilagoditvah preverjanja in ocenjevanja znanja učencev tujcev razlikujejo od stališč učiteljev predmetnega pouka; 3) katere prilagoditve preverjanja in ocenjevanja znanja učencev tujcev učitelji izvajajo po preteku dveletnega obdobja, ko so posamezne prilagoditve preverjanja in ocenjevanja dovoljene, in ali se pojavljajo razlike med učitelji razrednega ter učitelji predmetnega pouka; 4) kakšno je mnenje učiteljev glede pravičnosti prilagojenega preverjanja in ocenjevanja znanja učencev tujcev. Izsledki raziskave so pokazali, da učitelji, ki so med raziskavo poučevali tudi učence tujce, potrebo po prilagoditvah preverjanja in ocenjevanja znanja teh učencev prepoznavajo $\mathrm{v}$ večji meri kot učitelji, ki učencev tujcev med raziskavo niso poučevali. Ugotovili smo, da večina učiteljev, še zlasti učiteljev razrednega pouka, preverjanje in ocenjevanje znanja omenjenih učencev prilagojeno izvaja tudi po preteku uradno določenega dveletnega obdobja. Prilagoditve, ki jih izvajajo nekateri učitelji, pa obsegajo tudi zniževanje zahtevnosti meril ocenjevanja teh učencev. Večina učiteljev prilagojeno ocenjevanje označuje kot pravično, medtem ko so mnenja učiteljev o tem, ali bi bilo treba obdobje dovoljenih prilagoditev preverjanja in ocenjevanja znanja učencev tujcev podaljšati, deljena. Izsledki raziskave s tem odpirajo vprašanje o pojmovanju pravičnosti v izobraževanju med učitelji in aplikacijo načela pravičnosti v šolski praksi.

Ključne besede: prilagoditve preverjanja in ocenjevanja znanja, preverjanje in ocenjevanje znanja, pravičnost v izobraževanju, osnovnošolski učenci, učenci brez slovenskega državljanstva 


\section{Introduction}

Pupils without Slovenian citizenship who enrol in a Slovenian primary school $^{2}$ cope with many difficulties before achieving parity with their Slovenian classmates (i.e. pupils with Slovenian citizenship). They face a different environment from their own, a different language and a different education system with its own particularities. However, it is not only the starting point of a foreign pupil that is very different from that of a native Slovenian pupil. The results of the international study PISA (Programme for International Student Assessment) in 2009 show that the performance of immigrant pupils is incomparable with that of native pupils, especially in countries where native pupils perform exceptionally well and where foreigners do not speak the language of instruction at home (Šori, Šušterič, \& Gaber, 2011). ${ }^{3}$ Šori and colleagues claim that immigrant pupils 'do not gain the same benefits from the educational system' (ibid., p. 37). According to other secondary studies of the PISA results, this is obviously not a new trend. The results of a secondary study of PISA 2003 data, conducted by Levels and Dronkers (2008), implicate similar positions of migrant pupils in general. Their analysis included Australia, Austria, Belgium, Denmark, Germany, Greece, Ireland, Latvia, Liechtenstein, Luxembourg, New Zealand, Switzerland, and Scotland. The results of their study of the extent to which native and first- and second-generation migrants from various regions of origin, living in thirteen different countries of destination, differ in their scholastic ability showed that both the origin and destination of migration have significant effects on educational achievement, and that these effects play an important part in explaining differences in educational achievement between all three types of pupils. The authors claim that cross-national differences in these pupils' educational performance might be 'partly explained by different educational systems, by different policy measures concerning the reduction of socio-economic inequalities or by different immigration laws' (ibid., p. 1406). The research conducted by Scott, Webber, Lupart, Aitken, and Scott (2014) among Canadian educators showed that almost $60 \%$ of them perceived that students' cultural background affected the grades these students received.

2 Compulsory basic education in Slovenia is organised in a single structure nine-year basic school attended by children aged six to fifteen. Generalist teachers teach in the first five grades, and in some cases also in the sixth grade, while subject teachers teach pupils from the fourth to the ninth grade.

3 Immigrant pupils in this context are either first generation ('those born outside the country of assessment and whose parents were also born in another country') or second generation ('those born in the country of assessment but whose parents were born in another country') (OECD, 2010, p. 170). Therefore, pupils we regard as pupils without Slovenian citizenship are included in the wider group of immigrant pupils, and we assume that they face even greater challenges in the Slovenian education system than other pupils who fit the definition of immigrant pupils due to the language barriers and cultural differences they face. 
For an education system to be just, it is important to take the obstacles faced by pupils without the citizenship of the country of residence into consideration in education legislation and in educational practice. Some authors even express the need for the expansion of conceptualisation of special needs due to cultural, linguistic, and religious differences among pupils in the West (Scott et al., 2014; Webber \& Lupart, 2011).

According to the Elementary School Act (2006), pupils who are foreign citizens residing in the Republic of Slovenia are entitled to compulsory basic education on the same terms as Slovenian citizens. Additionally, they are offered adjustments that help them cope with instruction in a new language and cultural setting. Upon entering primary education, pupils who are Slovenian residents and whose mother tongue not Slovenian receive Slovenian language classes as well as instruction in their mother tongue in cooperation with the country of their origin. As far as assessment of knowledge is concerned, the Rules on Knowledge Assessment and Grading and Students' Progress to a Higher Class Standing in Elementary Schools (2013) define the right of a pupil without Slovenian citizenship to different assessment accommodations during a twoyear period starting with their enrolment in a Slovenian school. During this period, the knowledge of these pupils is assessed differently than that of pupils with Slovenian citizenship. Assessment accommodations, such as selection of assessment methods, number of examination periods, grades, etc., are chosen by the teachers' assembly at the school.

The present paper deals with assessment accommodations for pupils without Slovenian citizenship in the light of educational justice. For this reason, we asked primary school teachers in Slovenia about their perspectives on assessment accommodations for pupils without Slovenian citizenship, whether they accommodate the assessment and grading process for those pupils after the expiration of the allowed period of two years from enrolling in a Slovenian primary school, what kind of assessment accommodations they use, and whether they perceive the accommodations as being just or not.

\section{Justice in Education}

The conception of justice is traditionally bound to two basic notions that are presented by Aristotle in his work Nicomachean Ethics: 'the just as the lawful (universal justice) and the just as the fair and equal (particular justice)' (Aristotle, 2009 version, p. 80). In the first case, justice is paralleled with legality, so 
an act is just when it is in accordance with the law. ${ }^{4}$ The second notion defines a just act or a just law in the context of establishing or maintaining fairness of treatment. According to Aristotle, justice represents a virtue with two forms: the form of distributive justice and the form of rectificatory justice. In both cases, a just act is formally defined. Distributive justice concerns the fair distribution of wealth and other goods among the members of a certain community with regard to their individual merits. Rectificatory justice is, in contrast, concerned with the reestablishment of the position of a person before certain harm was inflicted on that person, who was therefore treated unjustly (ibid). Cicero's principle of distributive justice (to each his own) is connected to a law that defines what is theirs. This definition of justice is known as the fundamental definition of justice. Due to criticism of the definition of distributive justice with regard to the question what is theirs, different theories of justice suggest different principal criteria for deciding what is and what is not just. These criteria are: to each according to one's merits, to each according to one's abilities, to each according to one's works, or to each according to one's efforts. All these criteria are, however, bound to the concept of formal justice according to which the same beings must be treated in the same way, and different in a different way (Kodelja, 2006). ${ }^{5}$ According to Perelman (1963), individuals who are equal according to the chosen criteria must be treated in the same way. Because individuals are unequal in whichever characteristic we choose as the criterion, one has to form groups of individuals with the same level of the chosen characteristic and treat them equally within each group. This means that one has to apply the same rule for all of the individuals within a group. In the case of knowledge assessment, the same grades are thus given to the pupils who demonstrate the same level of knowledge. As formal justice does not define the criteria essential for the administration of justice but only sets the rule of its practical use, it is also called justice in application (Bobbio, 1995; Perelman, 1963).

Problems arise when two criteria for the administration of justice are being used. If one assesses the level of knowledge as well as the amount of effort invested in learning, and then two pupils demonstrate the same level of knowledge while investing a different amount of effort in their learning, it is not clear

4 Despite the definition of a just act as a legal act, and therefore an unjust act as an illegal act, Aristotle (2009 version) allows the possibility of the law itself being unjust. This may occur in a situation where an act is in accordance with the law but is at the same time inappropriate in terms of justice due to the universality of the law. In this case, the injustice of the law must be replaced by equity. According to Aristotle, 'the equitable is just, but not the legally just but a correction of legal justice' (ibid., pp. 98-99).

5 Perelman (1963) adds a few other criteria or conceptions of justice: to each the same thing, to each according to one's needs, to each according to one's rank, and to each according to one's legal entitlement. 
which grade they should receive. The reason for the confusion lies in the fact that the criteria to each according to one's works and to each according to one's efforts are being applied at the same time. If one followed the first criterion, both pupils would receive the same grade, but this would not be in accordance with the concept of formal justice because the second criterion requires taking into account the amount of effort invested in learning. If, in contrast, one did not give the pupils the same grade, the treatment would be unjust due to unequal treatment required by the first criterion (Kodelja, 2006). According to Perelman (1963), priority should be given to one essential characteristic (in our case knowledge or effort) at the expense of all the others. The essential characteristic is to be given the first consideration, while 'the rest [are] allowed to exert their influence only in so far as the primary one is not thereby disturbed' (ibid., p. 31).

\section{Equality of Opportunity in Education}

In socially and economically developed countries where the quantity of goods is limited, formal justice is manifested according to the principle of equality of opportunity. Besides providing equality of accessibility to education, the principle of equality of opportunity in education also includes the provision of equality of starting points in the educational process. These two conceptions of equality of opportunity are heterogeneous, as equality of accessibility of education is associated with a form, while equality of starting points is bound to material conditions and circumstances (Kodelja, 2006). Additionally, the principle of equality of accessibility forbids discrimination, while the principle of equality of starting points requires it. Measures for equalising pupils' starting points, in the sense of privileging the unprivileged (i.e., positive discrimination), are a means of equalisation of individuals' starting points. In this case, therefore, the inequality established by these measures is a means of achieving equality (Bobbio, 1995). Although positive discrimination policies particularly accentuate the need for implementing measures to nullify, or at least reduce inequalities in the starting points and results of underprivileged minorities, pupils without Slovenian citizenship find themselves in a similarly unequal position when enrolling in a Slovenian school, especially due to the linguistic and cultural differences they have to cope with.

Injustice in education is therefore connected to intentional or unintentional ignorance of the differences between pupils that are not a result of their work, invested effort, motivation, etc., but originate from the unequal natural distribution of abilities and talents, and from social inequalities that are beyond the pupil's control. Rawls's conception of justice as 'the first virtue of social 
institutions' (Rawls, 1999, p. 3) offers a solution for the unjust treatment of individuals or groups who are in an underprivileged position due to their ethnic, cultural or social origin. He defines two principles of justice for institutions:

First principle: Each person is to have an equal right to the most extensive total system of equal basic liberties compatible with a similar system of liberty for all.

Second principle: Social and economic inequalities are to be arranged so that they are both:

a) to the greatest benefit of the least advantaged, consistent with the just savings principle, and

b) attached to offices and positions open to all under conditions of fair equality of opportunity. (ibid., p. 266) ${ }^{6}$

The principle of fair equality of opportunity differs from the principle of formal equality of opportunity, which eliminates only legal obstacles in achieving certain social position or education. The essence of fair equality of opportunity lies in enabling the individual to genuinely achieve this social position or education. With regard to the unequal distribution of natural predispositions among individuals, those with equal abilities and talents should have equal opportunities for success despite the differences in their initial social status. However, equal abilities and talents are not the only factors of an individual's social success or academic achievement. A willingness to use these abilities, as well as aspirations and a capacity to gain from education, are also key factors in social success, and these factors have little to do with the biological dispositions of individuals. According to Rawls, these factors are primarily associated with a variety of social conditions that may present barriers to equal opportunities between individuals (ibid.). The author concludes that social inequalities should be corrected, while inequalities in the proved abilities and effort invested should be in favour of the most disadvantaged. As social inequalities can only be overcome to a certain extent, and given the fact that it is usually difficult to define exactly whether a certain inequality originates from social, biological, or individual inequalities, Meuret (2001) presents two solutions to this problem: one proposed by Walzer and the other by Rawls. Walzer suggests defining two phases of schooling. During the first phase (the elementary phase), the aim is to

6 The two principles are systematically ordered so that the first principle has priority over the second. The first priority rule claims that '(a) a less extensive liberty must strengthen the total system of liberties shared by all; (b) a less than equal liberty must be acceptable to those with the lesser liberty' (Rawls, 1999, p. 266). In contrast, the second principle of justice is lexically prior to the principle of efficiency and to the principle of maximising the sum of advantages, while fair equality of opportunity is prior to the difference principle. 
compensate for social and natural handicaps, as well as for differences in pupils' desire to learn. Thus, the goal of this phase is equality of results, which means one helps each child to master the same body of knowledge. Consequently, not all children are treated equally in the same way. The second phase (secondary education and schooling above the secondary level), in contrast, aims at enabling individuals to obtain as much education as their abilities allow. Rawls's solution is to apply an additional principle to the principle of fair equality of opportunity, i.e., the difference principle. According to this principle, 'an inequality of opportunity must enhance the opportunities of those with the lesser opportunity' (Rawls, 1999, p. 266).

According to Kodelja (2006), one of the basic rules of justice in education is the provision of knowledge assessment and progression in the education system on equal terms for everyone. Assessment is thus just when the grade received is equivalent to the knowledge demonstrated. It would, therefore, be unjust if a pupil who failed to achieve the educational standards progressed to another grade with others who did achieve these standards. However, it is equally unjust if one ignores the unequal starting points of pupils, for which they are not at fault, and provides equal opportunities on a formal level only. For Medveš (2002), this would not only imply injustice because of advancement under different terms, but also cause the school to take on less responsibility for the knowledge and potential development of such pupils.

Slovenian regulations on educational assessment in primary school consider both the principle of fair equality of opportunity and the difference principle. In the Rules on Knowledge Assessment and Grading and Students' Progress to a Higher Class Standing in Elementary Schools (2013), it is stated that, in agreement with parents, schools may accommodate the assessment and grading of a foreign pupil for as long as two years after the enrolment of the pupil in a Slovenian school. It is claimed that in this period a foreign pupil would overcome the differences (for the most part linguistic) that put him/her in an unequal starting position with regard to the other, native pupils. Accommodated assessment for pupils without Slovenian citizenship thus represents a means of positive discrimination in a broader sense. These pupils are in an underprivileged position, especially with regard to the language of instruction, so according to the principle of fair equality of opportunity, a kind of compensatory education is provided for them. The Act Amending the Elementary School Act (2011) establishes:

Children who reside in the Republic of Slovenia and do not speak Slovenian as their first language, [...] upon enrolment in primary school receive organised tuition in the Slovenian language and culture as well 
as tuition in their first language and their culture of origin in accordance with international treaties. (Article 1)

One may conclude that, according to legal provisions, the accommodation of treatment of pupils without Slovenian citizenship after the expiration of the allowed period of two years should be limited to the accommodations required by internal differentiation and individualisation due to individual differences between pupils. However, what are pupils', parents' and teachers' understandings of justice in education? According to the results of research conducted among French pupils, knowledge assessment is just when pupils who demonstrate the same level of knowledge receive the same grade (Kodelja, 2006). Similarly, research on Slovenian teachers' and parents' opinions on justice in assessment indicates that the majority of both teachers and parents are convinced that only knowledge should be included in assessment (Kovač Šebart \& Krek, 2009). In summary, the results of these studies show that in the opinion of pupils, teachers and parents it is necessary to respect an objective network of assessment that forms a clear, transparent measure and a precise procedure of measuring' (ibid., p. 203). These findings represent the basis for the present research conducted among Slovenian primary school teachers, the results of which are presented in the next part of the paper.

\section{Subject of the research}

The research addresses Slovenian primary school teachers' perspectives on assessment accommodations for pupils without Slovenian citizenship (mostly from former Yugoslav republics) and the assessment accommodations they practice for these pupils after the expiration of the legally defined period for different assessment accommodations.

The reason the research has been conducted with primary school teachers is that the accommodations of the assessment are only permitted by law in the primary schools. The following research questions are answered:

1. What are teachers' perceptions of assessment accommodations for foreign pupils; are there differences between teachers who had recently taught foreign pupils and those who had not? We aimed to determine whether the perceptions of teachers who had taught at least one pupil without Slovenian citizenship in the 2011/2012 school year (foreign pupils' teachers) are somewhat different from those of teachers who had taught only pupils with Slovenian citizenship (Slovenian pupils' teachers). 
2. Do generalist teachers have different perceptions than subject teachers?

3. What kind of assessment accommodations do teachers practice for these pupils after the expiration of the two-year period; do generalist and subject teachers act differently?

4. Do teachers perceive assessment accommodations as being just?

\section{Methodology}

Sample: The research was conducted on a representative sample of Slovenian primary school teachers in June 2012. It included generalist teachers and subject teachers from 79 primary schools in Slovenia. The schools were selected on the basis of region and size, which means that schools from all of the Slovenian regions were included, ensuring that schools from urban and rural environments were represented equally, as were larger and smaller schools. Completed questionnaires were returned by 301 generalist teachers and 396 subject teachers, from $76.0 \%$ of the primary schools included in the research. A detailed description of the sample is presented below.

In terms of gender, $88.3 \%$ of the sample is represented by women and $11.7 \%$ by men. Their average age was 42.67 years ( $\mathrm{SD}=8.68$ years), and they had 18.69 years of work experience ( $S D=10.36$ years). The largest proportion of the teachers had a university degree $(62.9 \%)$, while a third had a short-cycle college degree $(32.3 \%)$, 3.3\% had finished professional college, $1.4 \%$ had a postgraduate degree, and $0.2 \%$ had completed four-year upper-secondary school. With regard to the seniority of the teachers within the Slovenian public school system, $15.7 \%$ of our sample were among the lowest-ranking teachers, $34.3 \%$ had $1^{\text {st }}$ degree promotions, $44.8 \%$ had $2^{\text {nd }}$ degree promotions, and $5.2 \%$ had $3^{\text {rd }}$ degree promotions. A quarter of the generalist teachers taught in the first grade $(25.1 \%)$, a fifth in the third grade $(21.9 \%), 17.9 \%$ in the second grade and the same share in the fourth grade, while $16.7 \%$ of the generalist teachers taught in the fifth grade and $0.4 \%$ in the sixth grade. Amongst the subject teachers, more than half taught in the second and third cycles (55.5\%), 34.9\% only in the third cycle, and $4.8 \%$ in all three cycles. The smallest shares of the subject teachers taught in the first and second cycles $(2.4 \%)$ or only in the second cycle $(2.1 \%)$. A quarter of all of the teachers in the sample (25.5\%) taught at least one pupil without Slovenian citizenship in the 2011/2012 school year. Of these teachers, 62 were generalist teachers and 116 were subject teachers.

Instruments: The data were collected through two similar questionnaires (one for generalist teachers and one for subject teachers), which were prepared for the present research. The questions are tackling teachers' perceptions on different 
assessment accommodations and the elements they accommodate for pupils without Slovenian citizenship after the expiration of the legally defined period. A general question of whether they perceive the accommodated assessment and grading process for those pupils as just was posed as well as questions about their sex, age, number of years of teaching, level of education, grade they taught in (in the questionnaire for generalist teachers), subject they taught (in the questionnaire for generalist teachers), and number of pupils without Slovenian citizenship they taught. The questions were formulated on the basis of formal regulations regarding assessment accommodations for pupils without Slovenian citizenship (Act Amending the Elementary School Act, 2011; Rules on Knowledge Assessment and Grading and Students' Progress to a Higher Class Standing in Elementary Schools, 2013).

Data Collection and Analysis: A different number of questionnaires were sent to each of the selected schools, according to the number of classes of the same grade. The principals of the schools were asked to distribute the questionnaires to the teachers according to the alphabetical order of their last names.

The data were analysed using SPSS (21.0). They were treated on the level of descriptive and inferential statistics, using the frequency distribution of the attributive variables, basic descriptive statistics of the numerical variables, and the Pearson chi-square test.

Results and Discussion: The aim was to determine the teachers' perceptions of the types and duration of accommodated assessment for pupils without Slovenian citizenship in a Slovenian primary school. We therefore tested the differences in perceptions of foreign pupils' teachers and Slovenian pupils' teachers regarding six statements.

Statistically significant differences between foreign pupils' teachers and Slovenian pupils' teachers emerged in opinions concerning statement The knowledge of pupils without Slovenian citizenship and with a lack of Slovenian language knowledge should be assessed based on milder criteria than the knowledge of their Slovenian classmates, with $\chi^{2}(2)=13.338, \mathrm{p}<0.001$. Almost two thirds of foreign pupils' teachers (71.4\%) and more than half of Slovenian pupils' teachers $(57.0 \%)$ agreed with the statement. The share of those foreign pupils' teachers who did not agree with the statement was slightly smaller than that of Slovenian pupils' teachers (17.7\% vs. $20.5 \%)$, while the share of those who were undecided was higher among Slovenian pupils' teachers (22.5\%) than among foreign pupils' teachers (10.9\%).

Opinions on the statement Knowledge assessment of pupils without Slovenian citizenship may be performed using accommodated assessment methods did not differ significantly between foreign pupils' teachers and Slovenian pupils' teachers. The majority of both groups of teachers agreed with the statement 
( $88.7 \%$ vs. $84.3 \%$ ), while slightly more than $5 \%$ did not agree with it (5.6\% vs. $5.1 \%)$. The share of undecided respondents was slightly higher amongst Slovenian pupils' teachers (10.6\%) than foreign pupils' teachers (5.6\%).

Both groups of teachers also had similar opinions on the statement If necessary, dates of assessment may be adjusted for pupils without Slovenian citizenship. The majority of foreign pupils' teachers (79.2\%) as well as Slovenian pupils' teachers $(71.5 \%)$ agreed with the statement, while less than a fifth of the teachers did not agree with it (13.5\% vs. $16.4 \%)$. Again, the share of undecided is somewhat larger among Slovenian pupils' teachers (12.1\%) than among foreign pupils' teachers (7.3\%); however, the differences were not significant.

In contrast, significant differences emerged in the opinions of both groups of teachers regarding the statement The number of grades may be adjusted for pupils without Slovenian citizenship, with $\chi^{2}(2)=14.861, \mathrm{p}<0.001$. A higher share of foreign pupils' teachers agreed with the statement than Slovenian pupils' teachers (69.7\% vs. 53.4\%). Additionally, a quarter of Slovenian pupils' teachers disagreed with the statement (25.3\%), while the share of foreign pupils' teachers was smaller (19.7\%). A larger share of Slovenian pupils' teachers was undecided (21.3\%) than foreign pupils' teachers (10.7\%).

The opinions of both groups of teachers on the statement The determined period of allowed assessment accommodations for pupils without Slovenian citizenship should be longer than the currently allowed period of two years from their enrolment in a Slovenian primary school were similar. Approximately a third of foreign pupils' teachers agreed with the statement (34.5\%), while a third did not agree (33.3\%) and another third was undecided (32.2\%). Among Slovenian pupils' teachers, roughly a third agreed with the statement $(36.8 \%)$, while a quarter did not agree $(25.9 \%)$ and the largest share was undecided (37.3\%). The differences in answers were, however, insignificant.

Differences between the opinions of foreign pupils' teachers and Slovenian pupils' teachers regarding the statement The teaching process should be the same for pupils without Slovenian citizenship as for pupils with Slovenian citizenship from the beginning of their schooling proved to be significant: $\chi^{2}(2)=11.391$, $\mathrm{p}<0.05$. While the shares of teachers who agreed with the statement were similar among foreign pupils' teachers (19.1\%) and Slovenian pupils' teachers (20.6\%), the shares of those who disagreed with the statement were different (66.3\% among the first group and 53.0\% among the second group). Again in this case, the share of undecided was larger among Slovenian pupils' teachers (26.4\%) than among foreign pupils' teachers (14.6\%).

Within the group of foreign pupils' teachers, the opinions of generalist teachers were also compared with those of subject teachers regarding each of 
the six statements, but the differences proved to be insignificant for all of the statements.

Additionally, we wanted to determine whether foreign pupils' teachers accommodate assessment and grading after the allowed period of two years from the enrolment of a foreign pupil in a Slovenian school, and if so how. Table 1 contains the numbers and the shares of positive answers to different statements for all of the foreign pupils' teachers, and for generalist teachers and subject teachers separately.

Table 1. The number of foreign pupils' teachers who agree with the statements related to accommodated assessment of pupils without Slovenian citizenship after the expiration of the legally allowed period

\begin{tabular}{lcccccc}
\hline \multirow{2}{*}{ Statements } & $\begin{array}{c}\text { Generalist teachers } \\
(n=62)\end{array}$ & $\begin{array}{c}\text { Subject teachers } \\
(n=116)\end{array}$ & \multicolumn{2}{c}{$\begin{array}{c}\text { All teachers } \\
(n=178)\end{array}$} \\
\cline { 2 - 7 } & $\mathrm{f}$ & $\mathrm{f} \%$ & $\mathrm{f}$ & $\mathrm{f} \%$ & $\mathrm{f}$ & $\mathrm{f} \%$ \\
\hline $\begin{array}{l}\text { I do not accommodate the assessment } \\
\text { and grading process after the expira- } \\
\text { tion of the allowed period. }\end{array}$ & 22 & 35.5 & 63 & 54.3 & 85 & 47.8 \\
$\begin{array}{l}\text { I accommodate methods of assess- } \\
\text { ment. }\end{array}$ & 27 & 43.5 & 30 & 25.9 & 57 & 32.0 \\
I accommodate dates of assessment. & 9 & 14.5 & 23 & 19.8 & 32 & 18.0 \\
I accommodate the number of grades. & 9 & 14.5 & 6 & 5.2 & 15 & 8.4 \\
Other. & 14 & 22.6 & 9 & 7.8 & 23 & 12.9 \\
\hline
\end{tabular}

The largest share of foreign pupils' teachers stated that they did not accommodate the assessment and grading process after the expiration of the allowed period (47.8\%). However, almost a third of the respondents stated that they did continue to accommodate the methods of assessment (32.0\%), the majority of them indicating that they preferred to use oral examination rather than tests. Almost a fifth of the teachers indicated that they accommodated dates of assessment according to an agreement with the pupil, a performed announced assessment of knowledge, or extended deadlines for projects, seminars, etc. (18.0\%). Some teachers also stated that they accommodated the number of grades for pupils without Slovenian citizenship (8.4\%), explaining that these pupils get less grades than other pupils, especially in cases where the grades are based on tests. Additionally, a few teachers indicated that they also combined several grades into one, in order to motivate pupils for future learning. The majority of the teachers who stated that they performed other accommodations of assessment (12.9\%) indicated that they usually accommodated assessment 
criteria (i.e., lowering the expectations regarding the achievement of learning standards) or applied different accommodations according to individual foreign pupil's needs.

A comparison of the generalist teachers' answers with those of the subject teachers showed significant differences in statements regarding not accommodating the assessment and grading process for pupils without Slovenian citizenship after the expiration of the allowed period: $\chi^{2}(1)=5.740, p<0.05$. While the greatest share of subject teachers agreed with the statement, only a third of generalist teachers concurred, which leads to the conclusion that two thirds of the generalist teachers did in fact accommodate the assessment and grading process for pupils without Slovenian citizenship after the expiration of the allowed period. Significant differences also emerged in agreement with the statements about accommodating methods of assessment $\left(\chi^{2}(1)=5.806, p<0.05\right)$ and the number of grades $\left(\chi^{2}(1)=4.571, p<0.05\right)$. In both cases, a larger share of generalist teachers than subject teachers practised these accommodations. Furthermore, a greater number of generalist teachers than subject teachers stated that they lowered expectations regarding the achievement of learning standards with $\chi^{2}(1)=5.809, p<0.05$. Finally, the differences in statements regarding the accommodation of dates of assessments were statistically insignificant, as was the association between the level of education and the use of different assessment accommodations after the expiration of the allowed period.

The final question of the questionnaire was whether teachers perceived the accommodated assessment and grading process for pupils without Slovenian citizenship as just. The vast majority of foreign pupils' teachers as well as Slovenian pupils' teachers stated that such assessment was just $(85.9 \%$ vs. $89.0 \%)$. The differences in the opinions between generalist teachers and subject teachers of pupils without Slovenian citizenship were statistically insignificant, as was the association between the opinion and the level of the teacher's education.

\section{Conclusion}

The results indicate that the majority of both foreign pupils' teachers as well as Slovenian pupils' teachers concur with using lower criteria in assessing and grading the knowledge of pupils without Slovenian citizenship, although the share of foreign pupils' teachers appeared to be significantly higher than the share of Slovenian pupils' teachers. The results are highly similar regarding accommodation of the number of grades and overall agreement with the necessity of a different approach to the treatment of pupils without Slovenian 
citizenship compared to their Slovenian classmates in the educational process. In both cases, a larger share of foreign pupils' teachers than Slovenian pupils' teachers agreed with such treatment. Although the majority of teachers agreed with the accommodation of assessment methods and examination periods for pupils without Slovenian citizenship, they were not certain whether or not the duration of the normatively prescribed period of possible assessment accommodations should change. These results, as well as the fact that the differences in opinions between generalist teachers and subject teachers appeared to be statistically insignificant, lead us to the conclusion that teachers who have recent experience of teaching at least one pupil without Slovenian citizenship are more aware of the need for accommodations in the assessment of these pupils than teachers who have not.

As far as the use of assessment accommodations in practice is concerned, more than half of the foreign pupils' teachers stated that they did in fact practice various assessment accommodations after the expiration of the allowed period. For all of the accommodations, however, the share of generalist teachers was significantly larger than that of subject teachers, the only exception being adjustment of the assessment dates. In cases where teachers were not sure about the need for the extension of the set period for allowed assessment accommodations but nonetheless practiced accommodations after the expiration of the determined period, the question arises as to whether they answered with regard to the didactic principle of the individualisation that should be considered with each individual pupil. This certainly must not be true when lowering demands for pupils without Slovenian citizenship with regard to achieving knowledge standards, which proved to be the case with some teachers. The results indicate that some pupils without Slovenian citizenship obviously do not receive proper feedback on their knowledge, strengths and weaknesses, nor on how to improve in order to succeed in the educational process in the future. We regard this as unjust towards these pupils, who are equally entitled to achieve internationally comparable knowledge standards, but with regard to whom the achievement of these standards is not always demanded. The results of the secondary analysis of data from the PISA study show significant differences between native pupils' and immigrant pupils' reading achievement in Slovenia, as in the majority of other participating countries (Šori et al., 2011). The authors claim that the reasons for these differences lie in immigrant pupils' lower level of cultural capital, poor language proficiency, lower level of enjoyment in reading, pupils' use of less efficient summarising strategies, and the insufficient effort of countries to overcome these obstacles (ibid). However, the results of our research suggest another factor contributing to differences in the achievement of both groups of 
pupils: teachers' lower demands for pupils without Slovenian citizenship with regard to knowledge standards. This is equally unjust to pupils with Slovenian citizenship, who have to show a higher level of knowledge in order to receive the same grade as their foreign classmates. Nevertheless, almost all the teachers, regardless of the grade they taught or their level of education, perceived the accommodated assessment and grading process as just, which is obviously in contradiction with the legislation as well as with the principle of justice. Qualitative research would thus enable us to develop an in-depth understanding of teachers' assessment practices with pupils without Slovenian citizenship.

Why are there differences between generalist teachers and subject teachers in practicing assessment accommodations after the expiration of the determined period? Possible reasons may lie in the fact that, in some subjects, pupils are grouped according to their ability in the higher grades of Slovenian primary school, and the fact that subjects in higher grades are more differentiated and are not as focused on developing basic skills and abilities. Perhaps subject teachers also perceive older pupils as having attended a Slovenian school for a longer period than they actually have, whereas generalist teachers have a better insight into the knowledge and basic skills of the individual foreign pupil, as well as of the Slovenian pupil, due to the longer period spent with the pupils. Considering the overall results, we conclude that it is important to treat pupils according to the principle of fair equality of opportunity, and to help them overcome their initial weaknesses by providing foreign pupils with preparational courses on Slovenian language, Slovenian culture and to acquaint them with the educational system, by adjusting teaching methods as well as practicing different assessment accommodations for them. However, considering the teachers' answers regarding practicing assessment accommodations even after the determined period, it may be reasonable to 1) analyse the type and quantity of educational assistance pupils without Slovenian citizenship receive as well as the possibilities that are at their teachers' disposal to help them, thus investing more effort in developing mechanisms aimed at improving the achievements of pupils without Slovenian citizenship, or 2) consider the extension of the legally defined period of allowed adjustments in the assessment process. In any case, educating teachers about ways of improving the knowledge of pupils without Slovenian citizenship, and about the importance of investing more effort in helping the pupils to achieve this goal, is crucial. Obviously, many teachers do practise various assessment accommodations even after the determined period, while others do not. This raises questions about the justice of such inconsistency in the treatment of pupils without Slovenian citizenship. We are convinced that accommodation of assessment criteria, in the sense of lowering demands 
regarding the level of knowledge after the expiration of the normatively determined period (and outside the context of grouping pupils according to their abilities), results in the unjust treatment of all of the pupils, and more attention should therefore be devoted to this problem.

Finally, focusing on the exchange of information between generalist teachers and subject teachers regarding the level of knowledge, language skills and overall individual progress of a pupil without Slovenian citizenship is of great importance, and more attention should be devoted to this issue.

\section{References}

Aristotle. (2009). Nicomachean Ethics. Oxford: Oxford University Press.

Bobbio, N. (1995). Eguaglianza e libertà. Torino: Einaudi.

Kodelja, Z. (2006). O pravičnosti v izobraževanju [On Juctice in Education]. Ljubljana: Krtina.

Kovač Šebart, M., \& Krek, J. (2009). Justice in the Assessment of Knowledge: The Opinions of

Teachers and Parents. In A. Kozłowska \& J. Muršak (Eds.), Poland, Slovenia, the World: Challenges

of Present-day Education (pp. 193-207). Krakow: Andrzej Frycz Modrzewski Krakow University:

Krakow Society for Education.

Levels, M., \& Dronkers, J. (2008). Educational Performance of Native and Immigrant Children from Various Countries of Origin. Ethnic and Racial Studies, 31(8), 1404-1425.

Medveš, Z. (2002). Nova paradigma pravičnosti v šoli [The New Paradigm of Juctice in School]. Sodobna pedagogika, 53(5), 24-41.

Meuret, D. (2001). School Equity as a Matter of Justice. In W. Hutmacher, D. Cochrane \& N. Bottani (Eds.), In Pursuit of Equity in Education: Using International Indicators to Compare Equity Policies (pp. 93-111). New York, Boston, Dordrecht, London, Moscow: Kluwer Academic Publishers. OECD (2010). PISA 2009 Results: What Students Know and Can Do - Student Performance in Reading, Mathematics and Science (Volume I). Paris: OECD Publishing.

Perelman, C. (1963). The Idea of Justice and the Problem of Argument. New York: The Humanities Press.

Rawls, J. (1999). A Theory of Justice. Cambridge, MA: The Belknap Press of Harvard University Press. Scott, S., Webber, C. F., Lupart, J. L., Aitken, N., \& Scott, D. E. (2014). Fair and Equitable Assessment Practices for All Students. Assessment in Education: Principles, Policy \& Practice, 21(1), 52-70.

Šori, I., Šušterič, N., \& Gaber, S. (2011). Immigrant Students' Achievements in Croatia, Serbia and Slovenia in Context. CEPS Journal, 1(3), 31-50.

Webber, C. F., \& Lupart, J. (2011). Leading Intercultural inclusive schools: An International Perspective. International Studies in Educational Administration, 39(1), 3-18. 


\section{Biographical note}

MoJCA ŽVeglič Minelič is a teaching assistant for pedagogical methodology and statistics at the Faculty of Education, University of Ljubljana. She is a $\mathrm{PhD}$ student at the same faculty, and is writing a dissertation on methodological views of internal knowledge assessment in primary school. Her research area is educational assessment. 